\title{
Е. М. ГАНФМАН В ЭМИГРАЦИИ: ПСИХОЛОГИЧЕСКИЕ ИССЛЕДОВАНИЯ ЛИЧНОСТИ ВЫХОДЦЕВ ИЗ СОВЕТСКОГО СОЮЗА
}

\author{
А. А. Костригин \\ Российский государственный университет им. А. Н. Косыгина \\ (Технологии. Дизайн. Искусство)
}

\begin{abstract}
Аннотация: В статье анализируется биография и научное творчество Евгении Моисеевны Ганфман (1905-1973), русско-американского психолога, эмигрировавшего в юности из послереволюционной России. Рассматриваются вехи жизненного пути ученого и направления научной деятельности. Особое внимание уделяется такому направлению исследований, как особенности личности выходцев из Советского Союза, которые проводились Е. М. Ганфман в рамках Гарвардского проекта по изучению советской социальной системы (1950-1953). Описываются результаты нескольких исследований ученого по данной проблематике.

По материалам научного доклада на конференции «Кросс-культурные и междисциплинарные исследования в истории психологии: результаты и перспективы» (Москва, 24-25 ноября 2018 г.), проведенной в рамках проекта № 18-513-18017, поддержанного РФФИ.
\end{abstract}

Ключевые слова: российское психологическое зарубежье; эмиграция; история психологии; Е. М. Ганфман; советские эмигранты; психология личности; межличностное взаимодействие; Гарвардский проект по изучению Советской социальной системы

\section{E. M. HANFMANN IN EMIGRATION: PSYCHOLOGICAL STUDIES INTO THE PERSONALITY OF FORMER SOVIET CITIZENS}

\author{
A. A. Kostrigin
}

Kosygin Russian State University (Technology. Design. Art)

Abstract: The article analyses the biography and scientific work of Eugenia Moiseevna Hanfmann (1905-1973), a Russian-American psychologist, who emigrated from postrevolutionary Russia in her youth. The author considers milestones in the scientist's life and directions of her scientific activity. Particular attention is paid to the line of research of the personality traits of emigrants from the Soviet Union, which was conducted by E.M.Hanfmann in the framework of the Harvard project on the Soviet social system (1950-1953). The results of the scientist's several studies on this issue are described.

The research is based on the materials of the scientific reportat the conference "Cross-Cultural and Interdisciplinary Studies into the History of Psychology: Results and Prospects" (Moscow, 24-25 November 2018), held within the project No. 18-513-18017 supported by RFBR.

Keywords: Russian psychological expatriate community; emigration; history of psychology; E. M. Hanfmann; Soviet emigrants; personality psychology; interpersonal interaction; Harvard project on the Soviet social system 
В настоящее время возрастает интерес к изучению научного наследия русских психологов-эмигрантов, покинувших страну по различным причинам в XIX и XX в. (Дивногорцева, 2011; Костригин, 2016, 2018а; Люк, Волкова, 2011; Мазилов, 2017; Масоликова, 2016; Масоликова, Сорокина, 2011; Стоюхина, 2017). Данную область можно обозначить как «российское психологическое зарубежье». Данное понятие является составной частью понятия «российское научное зарубежье», описываемого В. П. Борисовым и М. Ю. Сорокиной (Борисов, 1994; Сорокина, 2010), и обозначаемого как «совокупность всех специалистов, имевших печатные труды и принимавших участие в деятельности российского научного сообщества, - граждан Российской империи / Российской республики / СССР / Российской Федерации, по различным причинам покинувших страну и / или работавших длительное время за рубежом» (Сорокина, 2010: 84-85).

Ставя задачу обоснования данного термина, исследовательской области и группы ученых, мы считаем, что под понятием «российское психологическое зарубежье» необходимо понимать группу психологов, философов и других мыслителей, разрабатывающих психологические вопросы, которые родились / жили в Российской империи / СССР / России, но покинувшие страну, а также писавшие на русском языке. Выделение данной области позволит рассматривать в конкретной стране эмиграции и в конкретный период разработанные психологами идеи с точки зрения влияния новых факторов на этот процесс (например, психологической традицией страны эмиграции, если ученый встроился в сообщество, личными обстоятельствами и др.); также возможен учет направлений психологической мысли, которые существовали до Октябрьской революции 1917 г. и «эмигрировали» отъездом и высылкой ученых-психологов после нее.

Анализ научного наследия эмигрировавших ученых-психологов по выделенным двум направлениям (продолжение отечественных традиций и усвоение новых идей места и интеллектуального контекста эмиграции) выражает специфику российского психологического зарубежья, в рамках которой ученый совмещает в себе несколько научно-психологических традиций. Также, вместе с миграцией русских ученых мигрировали и психологические идеи, что способствовало распространению отечественных психологических концепций.

Среди таких примеров мы обращаемся к научно-психологическому наследию русско-американского психолога Евгении Моисеевны Ганфман (1905-1973). Мы уже посвящали некоторые работы ее биографии и научному творчеству (Костригин, 2018bc). Здесь же мы кратко обозначим вехи ее жизненного пути и осветим такое направление ее научной деятельности, как изучение личности выходцев из Советского Союза. 
Научные труды Московского гуманитарного университета 2019 № 1

Е. М. Ганфман родилась в 1905 г. в Санкт-Петербурге, но после революции в 1920 г. (Российское научное зарубежье, 2010; Simmel, 1986) (по другим источникам - в 1921 г., см.: Жарова и др., 2018)) вместе с семьей эмигрирует в Ковно в Литве, затем в 1922 г. - в Германию, где поступает в Йенский университет им. Ф. Шиллера. Здесь она учиться у Вильгельма Петерса (1880-1963) и защищает диссертацию на тему «Формирование зрительных ассоциаций» (1927). В 1930-1932 гг. работает в лаборатории Курта Коффки в Колледже Смит (Нортгемптон, США) вместе с другими русскими эмигрантами Тамарой Дембо (1902-1993) и Марией Рикерс-Овсянкиной (1898-1993) и занимается изучением восприятия, памяти, воображения, мышления, опираясь на парадигму гештальтпсихологии. Результатом данного научного периода стали исследования пространственного восприятия у детей, восприятия фигур и их сравнения у взрослых и др.

В 1932-1935 гг. Е. М. Ганфман работает психологом в Ворчестерской государственной больнице (США) под руководством Дэвида Шакова (1901-1981) и знакомится с различными патопсихологическими феноменами: изучает социально-психологические вопросы лечения и взаимодействия пациентов и врачей в клинике, овладевает психодиагностическим инструментарием, работает с когнитивными нарушениями пациентов.

В 1936 г. Е. М. Ганфман переходит работать в Больницу Майкла Риза (Чикаго, США) совместно с Якобом (Джейкобом) Казаниным (1897-1946). Вместе они разрабатывают клинико-психологические и патопсихологические проблемы, развивают некоторые идеи Л. С. Выготского относительно развития понятийного мышления и когнитивных процессов у больных шизофренией (Выготский, 1932). Они модифицируют методику формирования искусственных понятий Выготского-Сахарова (The Hanfmann-Kasanin Concept Formation Test) (Выготский, 1982; Сахаров, 1930; Hanfmann, Kasanin, 1937). Изменив постановку задачи в методике, по их мнению, создается более определенная для испытуемого ситуации, при которой у него возникает установка на категоризацию и на инсайт, что позволяет четко увидеть процесс функционирования понятийного мышления. Далее Е. М. Ганфман изучает у психически здоровых личностные паттерны функционирования интеллекта. Она разделяет данные паттерны на перцептивные понятийные по доминантности одного когнитивного процесса над другим. Продолжая деятельность по распространению идей Л. С. Выготского, Е. М. Ганфман совместно с Гертрудой Вакар (1904-1973) переводит книгу Л. С. Выготского «Мышление и речь» (Thought and language) в 1962 г. (Vygotsky, 1962).

В 1939-1944 гг. работает ассистентом профессора в Колледже Маунт Холиок (Южный Хедли, Массачусетс) и под руководством Курта Гольдштейна (1878-1965) занимается вопросами психологии личности. 
В 1944-1946 гг. работает в научном коллективе при Управлении стратегических служб США (Фэрфакс) под руководством Генри Мюррея (18931988). Здесь они исследуют личностные и психические особенности военных и сотрудников спецслужб.

В 1946-1952 гг. она работает преподавателем клинической психологии на Отделении социальных отношений в Гарвардском университете и сотрудничает с Русским исследовательским центром. Последнее отражается в ее работах, посвященных изучению психологических особенностей личности выходцев из СССР, которые мы осветим подробнее ниже.

С 1952 г. и до конца своей жизни Ганфман работает профессором психологии и директором Центра психологического консультирования при Университете Брандайза (США). На эту должность ее рекомендовал Абрахам Маслоу (1908-1970). В это время Ганфман касается нового для себя направления: психологическое консультирование и психологическая коррекции личности и поведения студентов.

В достаточно разностороннем научном творчестве Е. М. Ганфман мы хотели бы остановиться на исследованиях личности выходцев из Советского Союза, которые были частью известного Гарвардского проекта по изучению Советской социальной системы (Harvard Project on the Soviet Social System) (1950-1953), в рамках которого проводились интервью с советскими эмигрантами, жившими в Европе и США (Inkeles, Bauer, 1961). Среди исследовательских вопросов этого периода можно отметить: личностные особенности русских эмигрантов в ситуациях межличностного взаимодействия, решения групповых задач, конфликта; советские психологические установки, сформированные под влиянием советских условий жизнедеятельности и тоталитарного режима, особенности психического здоровья и эмоционального реагирования и др. (Ганфман, Гетцельс, 2017; Beier, Hanfmann, 1956; Hanfmann, Getzels, 1955).

Дадим краткую характеристику двух исследований Е. М. Ганфман и ее коллег по данному направлению.

Исследуя особенности межличностного взаимодействия в рабочих условиях у советских эмигрантов, ученый с коллегами выявила (Ганфман, Гетцельс, 2017; Hanfmann, Getzels, 1955), что они склонны в управлении людьми к методам дисциплинирования, манипулирования, делегирования ответственности; в подчинении руководствуются мотивами, связанными с самоуважением, авторитаризмом, страхом; в согласии/отказе в помощи коллеге по работе руководствуются самозащитой и страхом репрессий; в отношении к слухам испытывают страх разоблачения и репрессий, воспринимают как угрозу; в сопротивлении групповому давлению руководствуются мотивами отсутствия желания удовлетворить потребности других, 
Научные труды Московского гуманитарного университета 2019 № 1

личной выгодой, страхом репрессий со стороны начальства, бесполезности группового плана в тоталитарной системе; в поддержке/уступке группе руководствуются приверженностью коллективу, дружбой, симпатией. Ведущей темой обсуждений рабочих условий и трудового взаимодействия в Советской системе являлась опасность для человека и угроза его жизни по политическим мотивам: любые частные действия отдельных лиц, будь то преднамеренные или непреднамеренные, могут быть истолкованы как самовольный подрыв режима, и, как таковые, строго наказываются. У большинства советских эмигрантов присутствовало стойкое чувство принадлежности к коллективу, понимание чувств и потребностей других людей и высокую положительную оценку этой принадлежности.

Также интересным исследованием было обращение к эмоциональным особенностям личности советских эмигрантов (Beier, Hanfmann, 1956): среди ведущих позитивных ценностей они отмечали эмоциональные переживания и простые чувственные удовольствия; в межличностных отношениях ими ценится принадлежность к другим как в эмоциональном, так и мировоззренческом плане; достаточно сильными являлись моральные ценности и патриотические чувства (патриотизм определялся как желание помочь русскому народу [«страдающему в тоталитарном государстве». $A . K]$.$) ; при этом не ярко выраженной ценностью для советских эмигрантов$ являлся личный успех и достижения. К ведущим негативным ценностям и источникам несчастья у советских эмигрантов относятся ограничительные условия жизни, сложность удовлетворения потребностей, угроза жизни, нарушение межличностных отношений и подрыв моральных ценностей.

Данные исследования являются уникальными как в научной организации, так и в плане выборки: советские послевоенные эмигранты были не просто «выборкой», но имеющей на себе печать тоталитарного режима. Вместе с тем, можно предположить и мотивацию участия в Гарвардском проекте Е. М. Ганфман: желание прикоснуться к родине хотя бы косвенно и помочь людям, жившим в страхе репрессий.

Евгения Моисеевна Ганфман относится к той уникальной группе русских ученых-психологов, которым удалось в XX в. совместить в своем творчестве и широкий спектр зарубежных психологических концепций, и отечественные традиции. В этом смысле мы безусловно относим научное наследие Е.М. Ганфман к российскому психологическому зарубежью, в котором остается та неразрывная связь человека с его родиной даже после разлуки с ней. 


\section{СПИСОК ЛИТЕРАТУРЫ}

Борисов, В. П. (1994) Истоки и формирование российского научного зарубежья // Культурное наследие российской эмиграции, 1917-1940 : в 2 кн. М. : Специализир. изд.-торг. предприятие «Наследие». Кн. 2 / под общ. ред. Е. П. Челышева, Д. М. Шаховского. С. 284-291.

Выготский, Л. С. (1932) К проблеме психологии шизофрении // Советская невропатология, психиатрия, психогигиена. Т. 1. Вып. 8. С. 352-364.

Выготский, Л. С. (1982) Собрание сочинений : в 6 т. М. : Педагогика. Т. 2. Проблемы общей психологии / под ред. В. В. Давыдова.

Дивногорцева, С. Ю. (2011) Наследие русского зарубежья: религиозная педагогика протоиерея В. В. Зеньковского и «Педагогика культуры» С. И. Гессена // Вестник Православного Свято-Тихоновского гуманитарного университета. Серия 4: Педагогика. Психология. № 2. С. 68-75.

Ганфман, Е., Гетцельс, Дж. (2017) Межличностные установки выходцев из Советского Союза: исследование с помощью полупроективной методики // История российской психологии в лицах: Дайджест. № 5. С. 12-73.

Жарова, Д. В., Кочнева, Е. М., Мурзина, Е. Б., Батыршина, А. Р. (2018) Женские имена в психологии: Евгения Ханфманн // Мир науки, культуры, образования. № 4 (71). С. 364-366.

Костригин, А. А. (2016) Педагогическая деятельность психологов-эмигрантов в Русском народном университете в Праге в первый год его работы (1923-1924) // История российской психологии в лицах: Дайджест. № 6. C. 227-240.

Костригин, А. А. (2018а) «В наше время, педагогически направленное»: студенческие психолого-педагогические штудии в Русском педагогическом институте им. Я. А. Коменского в Праге // Педагогика и просвещение. № 3. С. 46-64. DOI: 10.7256/2454-0676.2018.3.22753

Костригин, А. А. (2018b) Евгения Моисеевна Ганфман (1905-1973): последовательница Л. С. Выготского // Конференциум АСОУ : сборник научных трудов и материалов научно-практических конференций. № 2. С. 440-449.

Костригин, А А. (2018с) Евгения Моисеевна Ганфман (1905-1973): русская женщина в истории мировой психологии // Горожанки и горожане в политических, экономических и культурных процессах российской урбанизации XIV-XXI веков : Материалы Одиннадцатой международной научной конференции РАИЖИ и ИЭА РАН, 4-7 октября 2018 г., Нижний Новгород : в 2 т. / отв. редакторы: Н. Л. Пушкарева, Н. А. Гронская, Н. К. Радина. М. : ИЭА PAH. T. 2. C. 226-228.

Люк, Х., Волкова, М. В. (2011) Тамара Дембо: научный портрет на фоне XX века // Методология и история психологии. Т. 6. № 2. С. 40-73.

Мазилов, В. А. (2017) От алгоритма до ландаматики: несколько эпизо- 
дов из жизни профессора Л. Н. Ланды // История российской психологии в лицах: Дайджест. № 5. С. 93-106.

Масоликова, Н. Ю. (2016) К истории российского педагогического зарубежья в Великобритании: Николай Адольфович Ганс (1888-1969) // Ежегодник Дома русского зарубежья имени Александра Солженицына. Т. 6. С. 153-164.

Масоликова, Н. Ю., Сорокина, М. Ю. (2011) История российского научного зарубежья и психологическое сообщество // Методология и история психологии. Т. 6. № 2. С. 92-109.

Российское научное зарубежье: Материалы для биобиблиографического словаря (2010). Вып. 2: Психологические науки: XIX - первая половина ХХ в. / авт.-сост. Н. Ю. Масоликова, М. Ю. Сорокина. М. : Дом Русского Зарубежья им. А. Солженицына. 124 с.

Сахаров, Л. С. (1930) О методах исследования понятий // Психология. Т. 3. Вып. 1. С. 3-33.

Сорокина, М. Ю. (2010) Российское научное зарубежье versus русская научная эмиграция: к определению объема и содержания понятия «Российское научное зарубежье» // Ежегодник Дома русского зарубежья имени Александра Солженицына. М. : Дом русского зарубежья имени Александра Солженицына. С. 75-94.

Стоюхина, Н. Ю. (2017) Сергей Степанович Чахотин и НОТ: КОВОТЕП ОСВАГ - СССР // История российской психологии в лицах: Дайджест. № 5. C. $142-166$.

Inkeles, A., Bauer, R. A. (1961) The Soviet Citizen: Daily Life in a Totalitarian Society. Cambridge, Mass: Harvard Univ. Press.

Beier, H., Hanfmann, E. (1956) Emotional attitudes of former Soviet citizens, as studied by the technique of projective questions // The Journal of Abnormal and Social Psychology. Vol. 53. №. 2. P. 143-153.

Hanfmann, E., Getzels, J.W. (1955) Interpersonal attitudes of former Soviet citizens, as studied by a semi-projective method // Psychological Monograph: General and Applied. Vol. 69. № 4. P. 1-37.

Hanfmann, E., Kasanin,J.(1937) A method for the study of concept formation // The Journal of Psychology. Vol. 3. №. 2. P. 521-540.

Simmel, M. (1986) A tribute to Eugenia Hanfmann, 1905-1983 // Journal of the History of the Behavioral Sciences. Vol. 22. № 4. P. 348-356.

Vygotsky, L. (1962) Thought and language. Cambridge : MIT Press. 168 p.

Дата поступления: 15.01.2019 г.

Костригин Артем Андреевич - старший преподаватель кафедры психологии Российского государственного университета им. А. Н. Косыгина 
(Технологии. Дизайн. Искусство). Адрес: 117997, Россия, г. Москва, ул. Садовническая, д. 33, стр. 1. Тел.: +7 (977) 834-62-52. Эл. адрес: artdzen@gmail.com Kostrigin Artem Andreevich, Senior Lecturer, Department of Psychology, Kosygin Russian State University (Technology. Design. Art). Postal address: 33, Bldg. 1, Sadovnicheskaya St., Moscow, Russian Federation, 117997. Tel.: +7 (977) 834-62-52. E-mail: artdzen@gmail.com

\section{Для цитирования:}

Костригин А. А. Е. М. Ганфман в эмиграции: психологические исследования личности выходцев из Советского Союза [Электронный ресурс] // Научные труды Московского гуманитарного университета. 2019. № 1. URL: http://journals.mosgu.ru/trudy/article/ view/939 (дата обращения: дд.мм.гг.). DOI: 10.17805/trudy.2019.1.12 